\title{
The Analysis for the Scale and Efficiency of China's Major Automotive Enterprises Based on DEA Model
}

\author{
Zheng Fei ${ }^{1,2} \&$ Li L. $Z^{3}$ \\ ${ }^{1}$ School of Research Center of Collaborative innovation, Institute of Industrial Economy, Jiangxi University of Finance \\ and Economics, Nanchang, China \\ ${ }^{2}$ School of Accounting, Henan University of Economics and Law, Zhengzhou, China \\ ${ }^{3}$ School Jingdezhen Ceramics University, Jingdezhen, China \\ Correspondence: Zheng Fei, School of Industrial Economy, Jiangxi University of Finance and Economics, Nanchang, \\ Jiangxi, China, 330013.
}

Received: January 22, 2018 Accepted: February 5, 2018 Online Published: March 27, 2018

doi:10.5539/jmr.v10n2p129 URL: https://doi.org/10.5539/jmr.v10n2p129

Fund Project: National Social Science Fund Project "based on material flow accounting (MFA) of circular economy index system construction and evaluation" (project approval number 14BTJ002).

\begin{abstract}
This paper uses Data Envelopment Analysis (DEA) to measure the scale and efficiency of 28 major automotive enterprises in Chinese, and the results show that at this stage, large automobile manufacturers of China are under-produced and the production is too scattered, and the overall efficiency of automobile manufacturers is low. One of the main reasons is that because of the low technical efficiency value, the technological innovation capability of enterprises needs to be strengthened. The other reason is that the low efficiency of a large number of enterprises lowers the overall efficiency level. There is a positive correlation between the scale and efficiency of automobile manufacturers. Whether it is the horizontal comparison between different enterprises (nature) or the vertical comparison between the same enterprises, all show that compared with small-scale enterprises, large-scale manufacturing enterprises not only have higher scale efficiency but also have higher technical efficiency. With the expansion of production scale, the scale of enterprises and technical efficiency have improved, which shows that for the automotive industry, compared with other factors, economies of scale is the main factor that affects the automotive industry, and not only is it reflected in the scale but also in technological innovation. Therefore, when formulating policies, the relevant departments should support the development of large-scale enterprises, encourage mergers and acquisitions among enterprises, increase R\&D investment, support technological innovation, and set up a scientific market exit mechanism to reduce exit costs, such as guiding the transformation of enterprises and establish a competition mechanism for the survival of the fittest.
\end{abstract}

Keywords: DEA, automotive enterprises, scale; technical efficiency, scale efficiency

\section{Introduction}

In 1956, China's first car factory was put into operation, and now China's auto industry has 60 years of development history. In these 60 years, the development of automobile enterprises can be said to be rapid and achievements are enormous. According to the data from China Association of Automobile Manufacturers, the auto production and sales in 2015 exceeded 24.5 million vehicles to $24,503,300$ and 24,597,600 respectively, with an increase of $3.25 \%$ and $4.68 \%$ from the same period of last year, which is a record high in the history of the world, ranking first in the world for seven consecutive years. It was a veritable automotive producer. However, there were 113 automotive enterprises in China in 2013, which exceeded the sum of the number of automotive enterprises in the United States, Japan, Germany and South Korea. The sum of the output of the top 4 automobile manufacturers was 5.95 million units, accounting for only $25.09 \%$ of the national automobile output (CR4), and the output of the top 8 enterprises accounted for only $34.98 \%$ of the national output (CR8).But in the same period, Japan's CR4 was 19.33 million, accounting for $73.29 \%$, CR8 was $98.71 \%$. Germany's Volkswagen Group, Daimler Group, BMW Group, these three companies output 14.03 million units accounted for $83 \%$ of national output. And South Korea Hyundai Group, a total output of 801 million vehicles, accounted for $79.31 \%$ of the national output. So how much influence does low output and too fragmented organizational structure do to the efficiency of manufacturing enterprises? Can large-scale manufacturing enterprises produce higher-scale efficiency? Can 
large-scale manufacturing enterprises produce higher technical efficiency? What is the relationship between the scale and efficiency of car manufacturers? This is the problem that this paper tries to discuss.

Many scholars study the scale and efficiency of automobile industry production ,but the results are not the same. The well-known British economists Maxcy and Silberston made a large number of studies on the economies of scale of the automotive industry found that When the output of automobile enterprises increases from 1000 to 50000 , the average cost of enterprises (AC) will drop by $40 \%$; from 50,000 to 100,000 vehicles, the average cost will continue to drop by $9 \%$ on the previous basis; from 100,000 to 200,000 vehicles, the cost dropped by $5.5 \%$ from 100,000 vehicles. And they estimated the production technology and process level at that time, the optimal output of automobile companies is 20-30 million (Maxcy \& Silberston, 1954). Joachim Büschken, a German scholar, used the DEA model to study the input and output of advertising in Germany's automobile industry, and concluded that advertising efficiency is positively correlated with brand output(Büschken,2007). Hu Hongli, Bai Xuejie, Dai Xiaofei et al thought that the car business efficiency is too low by using the DEA method and the average economic data of China's sedan companies, and the problem of diseconomies of scale is a major obstacle to the development of sedan companies. The efficiency value that they used the average to calculate can only reflect the industry level, but there is no in-depth analysis of a single business(Hu Hongli,2004; Bai Xuejie,2006). He Yuangui, Zhang Jie et al used the 1993-2006 aggregate data of automotive enterprises and analyzed from the perspective of economies of scale. It is considered that the factors of R\&D investment and demand are the key factors which affect the economies of scale(He Yuangui et al,2009). However, in the process of analysis, the problem of product differentiation in the automotive market had not been taken into account, there was a big difference in passenger cars and commercial vehicles in the production, R\&D, sales, use, etc., so it lacked preciseness.

There are four methods for measuring efficiency: Engineering, Efficiency Frontier Analysis(EFA), Stochastic Frontier Analysis (SFA) and Data Envelopment Frontier Analysis(DEA), and the same point of the methods is to regard the production function or cost function as the "ideal state" or "frontier state" which are to be estimated. The benefits of engineering law are the high degree of compliance with the cost fixed coefficient; however, it is difficult to reflect the cost structure when firms convert between inputs based on the relative prices of inputs. EFA treats the theoretical construct as the ideal state that manufacturers may or may not achieve instead of treating the deviation of the cost function as a random item with a mean value of 0 , so it lacks feasibility. SFA and DEA are the most common ones in common use. Compared with SFA, DEA makes fewer assumptions about the functional frontier of production and is calculated by solving typical optimal problems instead of using standard The estimation algorithm is more general.

DEA method was proposed by Banker in 1984 and it was further researched in 1992 which made it equally applicable to the estimation of scale returns. The DEA method measures the relative efficiency in the sample, not the absolute efficiency, and it makes sense. And under the current level of demand and technical level, calculating the relative efficiency of the sample is the analysis of the status of the sample, we can visually see the problems with the sample itself to give targeted advice or suggestions. When using DEA measurements, to ensure the accuracy of the results, the number of decision-making units should be five times the input-output index or above. For existing studies, or there are too few samples; or there is a problem of incomplete analysis (ignoring the analysis of relative efficiency of specific business which is not conducive to the analysis specific business-specific); or the existence of accuracy and preciseness of the problem, which is not conducive to examine the size of the business and the link between the efficiency of the enterprise.

This paper takes production, operating income, total profits and taxes as input indicators, and takes total assets at the end of the year and the number of labor force at the end as output indicators, and there are analysis and comparison of different types of enterprises. This paper not only can scientifically measure the output scale of automobile manufacturers, but also makes up for the differences in the quality and use of their products. One of the purposes of the research is to make up for the deficiencies of the existing research. The other is to provide scientific and reasonable advice to the policy department in formulating industrial policies.

\section{The Model Construction and Selection of Indicators}

\subsection{Model Building}

One DEA model, which based on one input and one output, considers the maximum or frontier output for every kind of valid inputs. As shown in Figure 1 (a), where I1 represents an input element and Q1 represents an output element. This is a basic DEA model derived from the graph will be a frontier containing all the data (the value of the efficiency of the frontier is 1), and we find the minimum convex set of all the data points in the form. In order to test the technical efficiency of the workshop or business (which is marked as point $\mathrm{B}$ ) can measure the ratio of $\mathrm{AB} / \mathrm{AC}$, and this ratio represents the ratio of the number of outputs reached by the firm in using the inputs used and the estimated number of outputs in the production at the firm's inputs using at that level. For the situation of a single input of two kinds of output, the corresponding output is shown in figure 1(b), where I1 represents an input element and Q1,Q2 represents two output elements. Take automobile manufacturer as an example. It is assumed that workers in the enterprise can produce two 
different types of vehicles: one is a sedan and the other is an off-road vehicle. There is an alternative to each type of car that can be produced daily because any given worker can produce only one car at a time. In order to test the efficiency of production, we began to draw the line of the production of cars and SUVs for the employees of the enterprise, and then we can draw the results of figure (b). The data points in the figure represent the workers of an enterprise, and draw the frontier by finding the smallest convex set that envelops all the data points. The figure shows that there are some "technically effective" firms that are "on the cutting edge"; under other frontiers, other businesses have room to improve their technical efficiency. Its technical efficiency measurement ratio is: $\mathrm{OA} / \mathrm{OB}$, and $\mathrm{OA}$ and $\mathrm{OB}$ are the distance between point $\mathrm{A}$ and point $B$ to point $O$ respectively. The enterprise at point $B$ has a technical efficiency value of 1 . However, those running at points inside the frontier will run at a lower level of technical efficiency.
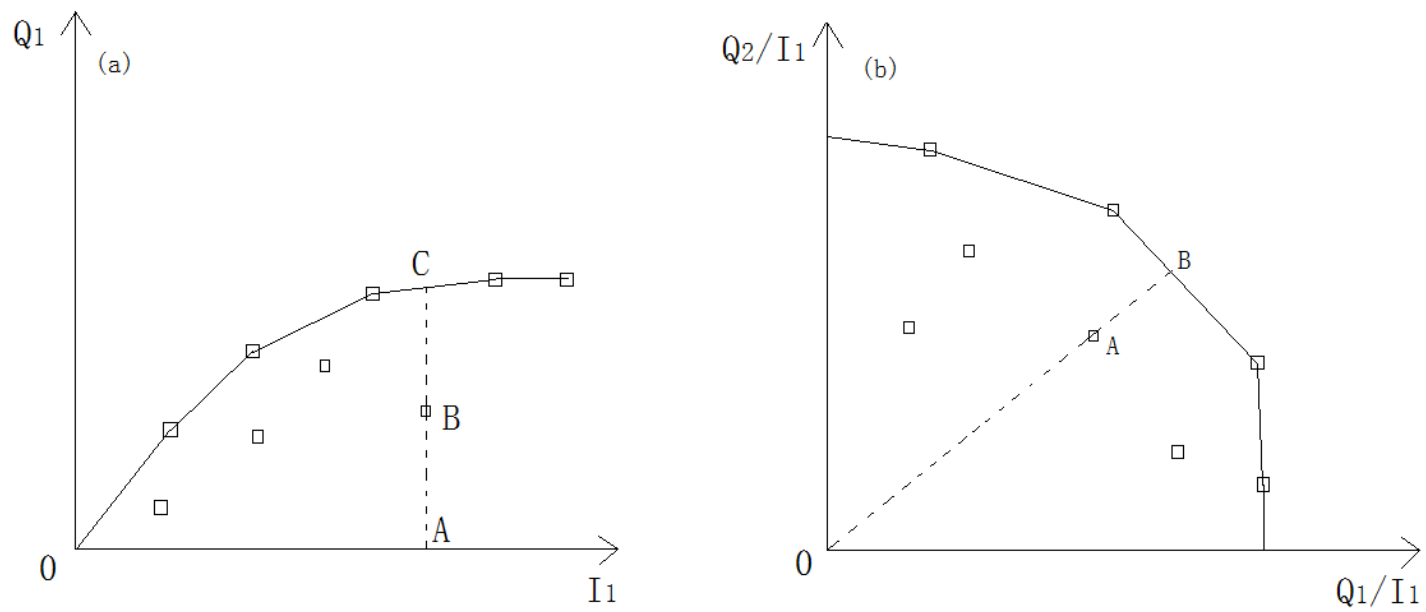

Figure 1. (a) the DEA model of a kind of output\& a kind of input, (b) the DEA model of two outputs and an input.

NOTE In figure 1,where I1 represents an input element and Q1 represents an output element. In figure 2, where I1 represents an input element and Q1,Q2 represents two output elements.

For the situations of a variety of inputs and outputs, it is difficult for graphics to express vividly, so we use numerical methods for similar analytical techniques for efficient production frontier. We define the output of firm $i$ as $q_{i}$, the number of input elements as $J$, and the input vector as $I_{i}=\left(I_{1 i}, I_{2 i}, \ldots I_{J i}\right)$. For other companies, such as company $k$, the estimated DEA for its efficiency is $\theta_{k}$, and it can be constructed by solving the minimization problem:

$$
\min _{\theta, r_{1}, \ldots, r_{j}}\left\{\theta \mid \frac{q_{k}}{\theta} \leq \sum_{i=1}^{n} r_{i} q_{i} ; I_{j k} \geq \sum_{i=1}^{n} r_{i} I_{j i}, j=1,2, \ldots, J ; \theta>0 ; r_{i} \geq 0 ; i=1,2, \ldots, n\right\}
$$

In the formula, A represents the constraint of the feasible combination of enterprises to express the attributes of the virtual manufacturer. Assuming that existing enterprises can only shrink and cannot expand, then $0 \leq r_{i} \leq 1_{n}$, virtual enterprises are built from a weighted combination of existing firm sizes, so we can attach a constraint $0 \leq \sum r_{i} \leq 1$; $\sum_{i}^{n} q_{i}$ is the weight of firm $i$ 's output; $\sum_{i}^{n} r_{i} I_{j i}$ is the virtual enterprise's input weighted; $q_{k} / \theta$ is the actual oütput drawn from firm $k$ on a pro-rata basis. Therefore, if we set the efficiency of a virtual enterprise to 1 , then $\theta$ measures the relative efficiency of existing and virtual enterprises. This model is based on output and input costs can be directly transformed by the output model:

If the input vector $j=1,2, \ldots, J$ of a firm $k$ is defined as $p_{k}=\left(p_{k 1}, p_{k 2}, \ldots, p_{k J}\right)$, and use the superscript "obs" to represent variables in the observed data and maintain previous output and input symbols, so an effective cost frontier can be defined by solving the equation.

$$
\min _{\substack{I_{k 1}, \ldots, I_{k J} \\ r_{1}, \ldots, r_{J}}}\left\{\sum_{j=1}^{J} p_{k l}^{o b s} I \mid q_{k}^{o b s} \leq \sum_{i=1}^{n} r_{i} q_{i}^{o b s} ; I_{k j} \geq \sum_{i=1}^{n} r_{i} I_{i j}^{o b s}, j=1,2, \ldots, J ; r_{i} \geq 0, i=1,2, \ldots, n\right\}
$$


For each enterprise $k$, the minimum cost vector $\left(I_{k 1}, I_{k 2}, \ldots, I_{k J}\right)$ of virtual enterprise input elements must satisfy (1) the output of the virtual firm is greater than or equal to the observed output of firm $k$; (2) the investment is the investment required by the virtual enterprise. The optimal cost level $C_{k}^{*}$ derived from this model is compared with the observed cost level $C_{k}^{o b s}$ to arrive at a measure of total efficiency $O E_{k}=C_{k}^{*} / C_{k}^{o b s}$ to observe the degree of difference between a put-in-put and an optimal put-together to measure the configuration effectiveness.

\subsection{The Selection of Evaluation System}

In the selection of variables, we can draw on the choice of indicators of Jiao Guohua (2007) and determine the actual situation of data collection: output indicators are car production, operating income and total profits and taxes; input indicators are the total assets at the end of the year and the number of employees at the end of the year. An innovation of this paper is to take production as an output indicator, and It is more direct and objective to measure output with the quantity of production. Operating income is a qualitative difference in production, and the total amount of profits and taxes not only measures the profits made by the enterprises, but also measures the contribution made by the enterprises to the taxes. The total assets at the end of the year include not only the input of fixed assets but also the investment of current assets, and the number of employees at the end of the year indicates the input of enterprises.

\subsection{Data Description and Analysis of the Description}

Based on the production and operation data of 67 passenger car vehicle manufacturers for the 10 years from 2008-2013 obtained from China Automotive Industry Yearbook, China Association of Automobile Manufacturers and the website of China Ministry of Industry and Information Technology: (1) In view of the isomorphism requirement, we will remove 67 enterprises producing commercial vehicles that also produce commercial vehicles, and only keep the production of passenger vehicles; (2)Taking into account the timeliness of the study, we removed automobile companies established after 2004; (3)To make the analysis more rigorous, all automobile groups all use their passenger car subsidiary as a decision-making unit (FAW-Volkswagen Automotive Co., Ltd., FAW Toyota Motor Co., Ltd., FAW Car Co., Ltd., FAW Xiali Automobile Co., Ltd. Company, FAW Haima Automobile Co., Ltd. belong to FAW Group controlled subsidiaries, which we set in the text as five decision-making unit); (4)We eventually got 28 car manufacturers as a decision-making unit group. The number of DMUs is more than 5 times the input-output items which meets DEA method requirements. (5)In order to exclude the impact of inflation, the above data in 2013 as the base period was adjusted. Data description is shown in Table 1: 
Table 1. Data Description on Output Factors and Input Factors (Unit: vehicles; million yuan; per capita)

\begin{tabular}{|c|c|c|c|c|c|}
\hline Variable & Observations & Average & Variance & Minimum & Maximum \\
\hline Production & 168 & 373190.4 & 340251.9 & 13631 & 2082628 \\
\hline $\begin{array}{l}\text { Operating } \\
\text { Income }\end{array}$ & 168 & 4625771 & 6251666 & 221768 & 47623134 \\
\hline $\begin{array}{c}\text { Total Profits } \\
\text { and Taxes }\end{array}$ & 168 & 804732.2 & 1179339 & 6685 & 8073697 \\
\hline $\begin{array}{l}\text { Total Assets at } \\
\text { the End of the } \\
\text { Year }\end{array}$ & 168 & 2474616 & 2486217 & 130765 & 17896996 \\
\hline $\begin{array}{c}\text { Year-end } \\
\text { employment }\end{array}$ & 168 & 11068.15 & 9829.388 & 3821 & 65504 \\
\hline
\end{tabular}

As can be seen from Table 1, from 2008 to 2013, the average production volume of China's automobile manufacturers was 373,000 , of which the maximum was $2,882,000$ and the minimum was only 13,000, and it shows that there is a big gap between the production scale of automobile manufacturers and also shows that the scale of automobile enterprises is growing rapidly. From the business income, total profits and taxes, changes in the total assets of the year-end also shows that there is a big gap between the business ability of enterprises, profitability and the scale of the enterprise.

\section{Empirical Results and Analysis}

\subsection{Analysis of Average Production Efficiency of Enterprises}

The output index and input index data of 28 major automobile manufacturers in China from 2008 to 2013 were respectively substituted into DEAP2.1 software, and the comprehensive technical efficiency value, pure technical efficiency value, scale efficiency value(as shown in Table 1).

Table 2. 2008-2013 China's major automobile manufacturer's average productivity changes

\begin{tabular}{c|c|c|c}
\hline Years & Comprehensive Technical Efficiency & Pure Technical Efficiency & Scale Efficiency \\
\hline 2008 & 0.657 & 0.726 & 0.901 \\
\hline 2009 & 0.691 & 0.760 & 0.907 \\
\hline 2010 & 0.758 & 0.823 & 0.919 \\
\hline 2011 & 0.706 & 0.781 & 0.901 \\
\hline 2012 & 0.665 & 0.722 & 0.921 \\
\hline 2013 & 0.645 & 0.690 & 0.938 \\
\hline
\end{tabular}

\subsubsection{Comprehensive Technical Efficiency Analysis}

The comprehensive technical efficiency is an evaluation of the overall operational efficiency of the industry and consists of pure technical efficiency and economies of scale. In general, the overall technical efficiency of China's automobile manufacturers from 2008 to 2013 experienced a process of first increasing, then decreasing. In 2010 was 0.758 which is the maximum. Compared with 2008, there was a decrease of 1.2 percentage points in 2013. As can be seen from Table 2 , the change trend of the integrated technical efficiency value converges with that of pure technical efficiency, while the change of scale efficiency is more stable. Therefore, it can be judged that the integrated technical efficiency value is more greatly influenced by pure technical efficiency.

\subsubsection{Pure Technical Efficiency Analysis}

The calculation of pure technical efficiency is the output capacity under the conditions of the established input elements, which mainly measures the operation and management level and innovation level of the enterprise. The pure technical efficiency of automobile manufacturers in 2008-2013 also went through the process of first rising (from 0.657 to 0.758 in 2008-2010) and then to declining (0.758-0.645 in 2010-2013), which also shows that pure technical efficiency is the main factor affecting the efficiency of China's automobile manufacturers. 


\subsubsection{Scale Efficiency Analysis}

Between 2008 and 2013, the average annual economies of scale efficiency was $20 \%$ higher than the purely technical efficiency, and although it also experienced first rising and then falling volatility over the six years, it tends to be flat compared to the purely technical efficiency and the average reached 0.938 , and this shows that compared with the pure technical efficiency, the simple scale factor is not the main factor affecting the efficiency of the automobile manufacturing industry.

\subsection{Analysis of the Relative Efficiency of Enterprises.}

In order to find out the further reasons for the inefficiency of automobile enterprises, we take 2013 as an example to carry out an analysis. The efficiency of each enterprise is calculated separately, and the relative efficiency of each automobile enterprise is analyzed in detail as shown in Table 3.

Table 3. Relative Efficiency of Major Chinese Car Manufacturers in 2013

\begin{tabular}{|c|c|c|c|c|c|c|c|c|c|}
\hline \multirow[b]{2}{*}{$\begin{array}{c}\text { Enterprise } \\
\text { Name }\end{array}$} & \multicolumn{2}{|c|}{ Equity } & \multirow[b]{2}{*}{$\begin{array}{l}\text { Product } \\
\text { ion } \\
\text { Scale } \\
\text { (unit) }\end{array}$} & \multirow[b]{2}{*}{$\begin{array}{c}\text { Size } \\
\text { Ranki } \\
\text { ngs }\end{array}$} & \multirow[b]{2}{*}{$\begin{array}{c}\text { Efficie } \\
\text { ncy } \\
\text { Rankin } \\
\text { gs }\end{array}$} & \multirow{2}{*}{$\begin{array}{c}\text { Compreh } \\
\text { ensive } \\
\text { Technical } \\
\text { Efficienc } \\
\text { y }\end{array}$} & \multirow{2}{*}{$\begin{array}{l}\text { Pure } \\
\text { Techn } \\
\text { ical } \\
\text { Effici } \\
\text { ency }\end{array}$} & \multirow[b]{2}{*}{$\begin{array}{l}\text { Scale } \\
\text { Effici } \\
\text { ency }\end{array}$} & \multirow{2}{*}{$\begin{array}{c}\text { Scale } \\
\text { Efficien } \\
\quad \text { cy } \\
\text { Charact } \\
\text { eristics }\end{array}$} \\
\hline & $\begin{array}{c}\text { Dome } \\
\text { stic } \\
\text { Capit } \\
\text { al\% }\end{array}$ & $\begin{array}{c}\text { Foreign } \\
\text { Capital } \\
\%\end{array}$ & & & & & & & \\
\hline $\begin{array}{c}\text { Shanghai } \\
\text { GM }\end{array}$ & 50 & 50 & $\begin{array}{c}208262 \\
8\end{array}$ & 1 & 1 & 1.000 & 1.000 & 1.000 & - \\
\hline $\begin{array}{c}\text { Shanghai } \\
\text { Volkswagen }\end{array}$ & 51 & 49 & $\begin{array}{c}155946 \\
9\end{array}$ & 2 & 5 & 0.998 & 1.000 & 0.998 & $\mathrm{drs}$ \\
\hline $\begin{array}{c}\text { FAW-Volks } \\
\text { wagen }\end{array}$ & 70 & 30 & $\begin{array}{c}153773 \\
2\end{array}$ & 3 & 1 & 1.000 & 1.000 & 1.000 & - \\
\hline $\begin{array}{l}\text { Beijing } \\
\text { Hyundai }\end{array}$ & 50 & 50 & $\begin{array}{c}104001 \\
8\end{array}$ & 4 & 8 & 0.878 & 0.896 & 0.980 & drs \\
\hline $\begin{array}{l}\text { Dongfeng } \\
\text { Nissan }\end{array}$ & 50 & 50 & 946306 & 5 & 16 & 0.517 & 0.543 & 0.953 & drs \\
\hline $\begin{array}{c}\text { Changan } \\
\text { Ford }\end{array}$ & 50 & 50 & 684468 & 6 & 13 & 0.730 & 0.758 & 0.963 & $\mathrm{drs}$ \\
\hline $\begin{array}{c}\text { Great Wall } \\
\text { Motor }\end{array}$ & 100 & 0 & 638327 & 7 & 27 & 0.304 & 0.406 & 0.749 & drs \\
\hline $\begin{array}{c}\text { Tianjin } \\
\text { FAW Toyota }\end{array}$ & 50 & 50 & 554749 & 8 & 1 & 1.000 & 1.000 & 1.000 & - \\
\hline Dragon & 50 & 50 & 554457 & 9 & 21 & 0.399 & 0.431 & 0.926 & drs \\
\hline $\begin{array}{l}\text { Dongfeng } \\
\text { Yueda Kia }\end{array}$ & 50 & 50 & 548990 & 10 & 10 & 0.802 & 0.821 & 0.977 & irs \\
\hline $\begin{array}{c}\text { Zhejiang } \\
\text { Geely }\end{array}$ & 100 & 0 & 548842 & 11 & 18 & 0.428 & 0.439 & 0.974 & $\mathrm{drs}$ \\
\hline BYD & 100 & 0 & 510950 & 12 & 6 & 0.975 & 0.979 & 0.996 & irs \\
\hline $\begin{array}{l}\text { Guangqi } \\
\text { Honda }\end{array}$ & 50 & 50 & 438847 & 13 & 11 & 0.787 & 0.796 & 0.989 & irs \\
\hline Chery & 100 & 0 & 436703 & 14 & 7 & 0.966 & 1.000 & 0.966 & drs \\
\hline $\begin{array}{c}\text { Dongfeng } \\
\text { Honda }\end{array}$ & 50 & 50 & 325842 & 15 & 9 & 0.866 & 0.931 & 0.931 & irs \\
\hline Guangzhou & 50 & 50 & 302983 & 16 & 1 & 1.000 & 1.000 & 1.000 & - \\
\hline
\end{tabular}




\begin{tabular}{|c|c|c|c|c|c|c|c|c|c|}
\hline $\begin{array}{c}\text { Automobile } \\
\text { Toyota }\end{array}$ & & & & & & & & & \\
\hline FAW Car & 53 & 47 & 249830 & 17 & 24 & 0.367 & 0.371 & 0.989 & irs \\
\hline $\begin{array}{c}\text { Brilliance } \\
\text { BMW }\end{array}$ & 50 & 50 & 214978 & 18 & 19 & 0.424 & 0.428 & 0.990 & drs \\
\hline $\begin{array}{c}\text { Anhui } \\
\text { Jianghuai }\end{array}$ & 100 & 0 & 206132 & 19 & 28 & 0.287 & 0.289 & 0.996 & irs \\
\hline $\begin{array}{c}\text { Dongfeng } \\
\text { Liuzhou }\end{array}$ & 100 & 0 & 182057 & 20 & 20 & 0.400 & 0.412 & 0.969 & irs \\
\hline Chongqing & & & & & & & & & \\
\hline $\begin{array}{c}\text { Changan } \\
\text { Suzuki }\end{array}$ & 60 & 40 & 141988 & 21 & 14 & 0.623 & 0.687 & 0.906 & irs \\
\hline $\begin{array}{c}\text { FAW Xiali } \\
\text { Nanjing }\end{array}$ & 100 & 0 & 129025 & 22 & 23 & 0.381 & 0.401 & 0.952 & irs \\
\hline $\begin{array}{c}\text { Automobile } \\
\text { Group }\end{array}$ & 100 & 0 & 136589 & 23 & 26 & 0.332 & 0.338 & 0.984 & irs \\
\hline $\begin{array}{c}\text { Beijing } \\
\text { Benz }\end{array}$ & 50 & 50 & 118819 & 24 & 25 & 0.357 & 0.366 & 0.976 & irs \\
\hline $\begin{array}{c}\text { Southeast } \\
\text { Fujian }\end{array}$ & 50 & 50 & 114140 & 25 & 12 & 0.762 & 0.935 & 0.815 & irs \\
\hline $\begin{array}{c}\text { hippocampu } \\
\text { s }\end{array}$ & 100 & 0 & 108478 & 26 & 22 & 0.393 & 0.432 & 0.911 & irs \\
\hline $\begin{array}{c}\text { Jiangxi } \\
\text { Changhe }\end{array}$ & 100 & 0 & 82819 & 27 & 15 & 0.547 & 0.669 & 0.818 & irs \\
\hline Honda car & 50 & 50 & 24000 & 28 & 17 & 0.512 & 1.000 & 0.512 & irs \\
\hline $\begin{array}{c}\text { Average } \\
\text { Value }\end{array}$ & & - & $\begin{array}{c}515005 \\
.9\end{array}$ & _. & - & 0.645 & 0.690 & 0.938 & - \\
\hline
\end{tabular}

According to the calculation results, among the 28 automobile manufacturers, there are 4 enterprises that can achieve the best efficiency: Shanghai GM, FAW-Volkswagen, Tianjin FAW Toyota Motor Co. and Guangzhou Automobile Toyota Motor Co., which are all joint ventures. There are 15 enterprises in increasing scale efficiency, accounting for $54 \%$ of the total number of enterprises, which shows that the general above enterprises have the problem of insufficient output and the need to increase their output level in order to improve the efficiency of enterprises. There are nine enterprises in decreasing scale efficiency, indicating that these enterprises have some problems of overproduction to varying degrees. All of them are non-scale and effective enterprises. There are 7 enterprises with economies of scale above $0.9,3$ enterprises between $0.8-0.9,18$ enterprises below 0.8 , accounting for $64 \%$ of the total, indicating that there are a lot of low-middle-level efficient businesses. One of the reasons is that due to the consideration of fiscal and taxation, local governments will give protection to local enterprises and cause a large number of "zombie" enterprises to exist. On the other hand, it shows that enterprises have higher exit barriers. The automobile industry is a capital-intensive and technology-intensive industry. When enterprises exit the market, they face both the sunk cost of assets and the resettlement costs of unemployed people. It is difficult to make up for these losses solely by the power of the enterprises, and these costs constitute a kind of barrier that hinders the enterprises' free withdrawal.

Next, we classify the 28 enterprises according to their ownership structure and production scale, and calculate their average efficiency. On the one hand, it is easier to distinguish between different types of enterprises of different sizes and their efficiency; On the other hand, the classification of the average efficiency can avoid the impact of sudden behavior of enterprises on the efficiency, which is more scientific and general. 
Table 4. Average Efficiency of Joint Ventures and State-owned Enterprises

\begin{tabular}{c|c|c|c|c|c|c|c}
\hline $\begin{array}{c}\text { Types of } \\
\text { Enterpris } \\
\text { es }\end{array}$ & $\begin{array}{c}\text { Number } \\
\text { of } \\
\text { Enterpris } \\
\text { es }\end{array}$ & $\begin{array}{c}\text { Domestic } \\
\text { Investme } \\
\text { nt }\end{array}$ & $\begin{array}{c}\text { Foreign } \\
\text { Investme } \\
n t\end{array}$ & $\begin{array}{c}\text { Average } \\
\text { Productio } \\
\text { n Scale }\end{array}$ & $\begin{array}{c}\text { Pure } \\
\text { Comprehensi } \\
\text { ve Technical } \\
\text { Efficiency }\end{array}$ & $\begin{array}{c}\text { Technica } \\
1 \\
\text { Efficienc } \\
\text { Scale }\end{array}$ & $\begin{array}{c}\text { Efficienc } \\
\text { y }\end{array}$ \\
$\begin{array}{c}\text { Joint } \\
\text { Ventures }\end{array}$ & 18 & $52 \%$ & $48 \%$ & 635569.1 & 0.723 & 0.776 & 0.939 \\
State-own \\
$\begin{array}{c}\text { Enterpris } \\
\text { es }\end{array}$
\end{tabular}

From the ownership structure of view, 28 automobile manufacturers in 18 joint ventures accounted for $64.3 \%$ of the total, and there are 10 state-owned enterprises, accounting for less than $36 \%$ of the total number of enterprises, which shows that the automobile market in developed countries tends to be saturated. This makes the automobile industries in the United States, Japan, Germany and South Korea have to seek a way out from the emerging markets, thus strengthening the offensive on the Chinese auto market. At the same time, it reflects the result of China's industrial policy of "replacing the market by technology" with the automobile industry. Among the joint ventures, the ratio of domestic investment to foreign investment is close to 1: 1 , meaning that half of the profits earned by the joint ventures are owned by foreign enterprises. The average production scale of joint ventures is 636,000 units, which is more than twice the average production scale of state-owned enterprises, coupling with the introduction of advanced foreign technology joint ventures, which is more conducive to generating economies of scale. Therefore, its average comprehensive technical efficiency is higher than that of state-owned enterprises by 22.2 percentage points. The gap is mainly reflected in purely technical efficiency, and scale efficiency is basically the same. It shows that, compared with the joint venture, the technological innovation of the state-owned automobile enterprises is the focus of promotion and development.

Table 5.The Average Efficiency of Different Production Scale Enterprises

\begin{tabular}{c|c|c|c|c|c}
\hline Production Scale & $\begin{array}{c}\text { Number of } \\
\text { Enterprises }\end{array}$ & $\begin{array}{c}\text { Average } \\
\text { Production } \\
\text { Scale }\end{array}$ & $\begin{array}{c}\text { Comprehensive } \\
\text { Technical } \\
\text { Efficiency }\end{array}$ & $\begin{array}{c}\text { Pure } \\
\text { Technical } \\
\text { Efficiency }\end{array}$ & $\begin{array}{c}\text { Scale } \\
\text { Efficiency }\end{array}$ \\
\hline More than 2 million & 1 & 2082628 & 1 & 1 & 1 \\
1.5 million -200 million & 2 & 1548600 & 0.999 & 1 & 0.999 \\
$800,000-1.1$ million & 2 & 993162 & 0.698 & 0.72 & 0.97 \\
$500,000-80$ million & 7 & 577254.7 & 0.663 & 0.69 & 0.94 \\
$200,000-50$ million & 8 & 310759.3 & 0.671 & 0.688 & 0.98 \\
200,000 or less & 8 & 115323.9 & 0.479 & 0.582 & 0.871 \\
\hline
\end{tabular}

In terms of production scale, Shanghai GM Motor Co., Ltd., one of the companies that produced more than 2 million vehicles in 2013, had a production volume of 2.08 million units. Compared with other enterprises, its comprehensive technical efficiency, pure technical efficiency and economies of scale have reached the optimal. There are two enterprises with a production capacity of 1.5-2.0 million units, namely Shanghai Volkswagen Automotive Co., Ltd. and FAW-Volkswagen Automotive Co., Ltd. The average production scale reached 1.5486 million units. Although its average comprehensive technical efficiency did not reach the optimal, they reached a higher level. At this point, the overall technical efficiency is mainly affected by the scale efficiency, indicating the loss of efficiency due to the lack of output. There are two enterprises with a production capacity of 800,000 to 1,100,000, namely Beijing Hyundai Motor Co., Ltd. and Dongfeng Nissan Automobile Co., Ltd., with an average production scale of nearly 1 million vehicles, reaching 993,000 vehicles and an overall technical efficiency of 0.7 , and they are subject to pure technical efficiency constraints and economies of scale. Taken together, four of the 28 vehicle manufacturers in China have reached more than 1 million 
vehicles and their production scale has reached a relatively high level. Throughout the developed countries car production, in 2013 the world's top five best-selling brand vehicles, Japan's Toyota Motor Corporation, Hyundai Motor Company of Korea, the United States General Motors and Ford Motor Company in its local production and China's auto companies in the domestic production are about the same, which are 3.62 million, 2.8 million, 2.35 million, 830,000 and 550,000 respectively. This shows that in terms of production scale, the biggest problem in the automotive industry is not the output but the production is too scattered, small-scale enterprises are ubiquitous and the number of issues. From Table 4, we can see that with the increase of production scale, the overall technical efficiency, pure technical efficiency and scale efficiency of enterprises have been improved, and large enterprises have a higher overall efficiency, which shows that both the scale of production or technical level, large enterprises are better than small and medium enterprises. However, the main reason for the low efficiency of China's automobile enterprises is the large number of SMEs and inefficient enterprises ( 7 enterprises from 500,000 to 800,000, 8 enterprises from 200,000 to 500,000, and 8 enterprises from less than 200,000), making the overall efficiency of auto companies at a lower level. Among the 28 sample companies, 10 enterprises with low efficiency value accounted for $36 \%$ of the total sample, and the proportion of low-efficiency enterprises was high, indicating that the exit mechanism of China's automobile industry market is not perfect.

\subsection{Further Discussion About the Size and Efficiency of the Business}

In order to further verify the increase of production scale and improve the efficiency of enterprises, we choose the enterprises with the top 4 production capacities to do further analysis, which are Shanghai General Motors Co., Ltd., Shanghai Volkswagen Automotive Co., Ltd., FAW-Volkswagen Automotive Co., Ltd. and Beijing Hyundai Motor Co., Ltd., and draw their scatter plots and their fit lines using stata13.0 software for their production scale and efficiency data from 2004-2013. As can be seen from Figure 2, both the linear fit and the non-linear fit, the firm's production scale and overall technical efficiency are positively correlated. During the period 2004-2013, the production scale of the four enterprises continued to expand. Shanghai General Motors, for example, its production scale expanded from 2.5 million to 2.08 million, an increase of 8 times. Over the 10 years, the company's production of more than 2 million years in a year, 1 million -200 million years between the three years (the average production scale of 1,196,000), 200,000 -50,000 between the Year six years (average production capacity of 398,500), it can be said that the company's production increased faster and faster. During the period 2004-2009, the average production capacity was 398,500 units, with an overall technical efficiency of 0.78 . During 2009-2012, the average capacity was 1,196,000 units and the integrated technical efficiency was 0.957 . The production scale in 2013 was 2.08 million units. This further validates the previous conclusion: the scale of production and integrated technical efficiency values are positively correlated. The non-linear fit map further shows that when the production volume of 1.3 million -1.5 million units, the overall efficiency of enterprises achieve the highest, indicating that the current stage of China's auto industry's best production scale range of 130-150 million units.
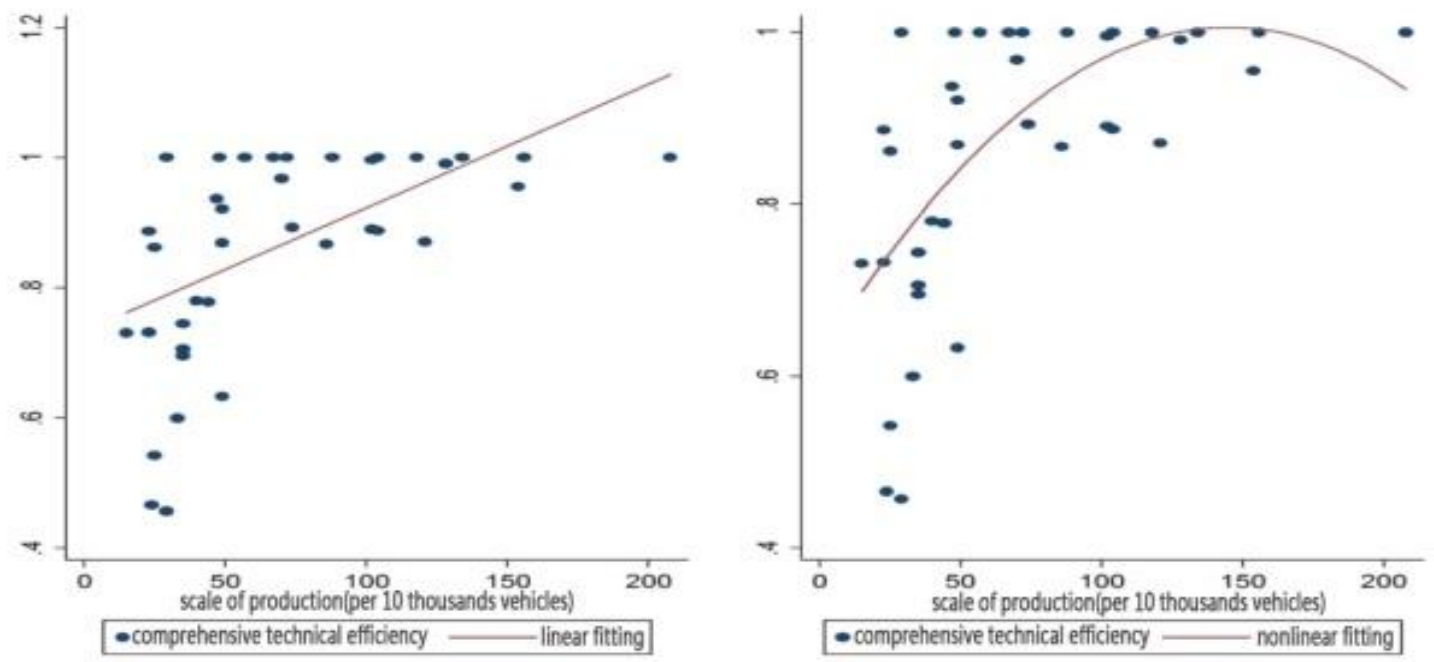

Figure 2. Production Scale and Overall Efficiency of Top 4 Enterprises in China's Production during 2004-2013.

NOTE the horizontal axis shows the scale of production(ten thousand),the vertical axis shows the comprehensive technical efficiency. 


\section{Conclusion and Policy Recommendations}

The empirical results show that at this stage, there are fewer large-scale automobile manufacturers in China and the total number of enterprises is too large, and the problems of over-decentralized production, low output and inefficient enterprises are widespread. It shows that the exit mechanism of the enterprise is unscientific and imperfect. The average efficiency of state-owned enterprises is lower than the joint-venture enterprises, and mainly reflected in the lack of innovation and technological backwardness. Therefore, strengthening technological progress is a strategic choice to improve the productivity of enterprises. From the above analysis, we can see that both the average efficiency analysis of different production scales and the time series analysis of the top 4 enterprises in production all show that with the expansion of the production scale of automobile enterprises, both the technical efficiency and the scale efficiency has increased. There is a positive correlation between the size and efficiency of enterprises, and the average efficiency of enterprises with large production scale is higher than that of enterprises with small production scale. Therefore, we should further increase the production scale of enterprises and support the development of large enterprises.

(1)Strengthen mergers and acquisitions among automobile enterprises and increase market concentration. Empirical evidence shows that there is a positive correlation between the scale of production and the efficiency of enterprises. Compared with small and medium enterprises, large-scale manufacturing enterprises have higher scale efficiency and pure technical efficiency. With the expansion of production scale, enterprises have higher efficiency. At this stage, the economy of scale is still the most important factor for automobile manufacturers. In recent years, with the development of automobile industry, the scale of automobile manufacturing enterprises has been gradually expanded, resulting in a series of large-scale and efficient automobile manufacturing enterprises such as Shanghai General Motors, Shanghai Volkswagen, FAW-Volkswagen, Beijing Hyundai, etc., driving the rapid development of China's automobile industry. However, compared with developed countries (the United States, Japan, Germany, South Korea, etc.), the number of large-scale automobile manufacturers in our country is relatively small and the production is too scattered. Therefore, our country should strengthen the merger and reorganization between enterprises and increase the market concentration. On the one hand, large-scale manufacturing enterprises are conducive to produce economies of scale in production and should reduce the production costs of enterprises; on the other hand, it can prevent the consequences of "bad money drives out good money" caused by excessive and malicious price cuts caused by too many car companies.

(2)Set up a scientific exit mechanism to reduce exit costs. There are several ways for an enterprise to withdraw from the market such as enterprise restructuring, upgrading, stopping production and going bankrupt. The government should set up a special compensation fund to provide different exit compensation according to different enterprises and provide financial support and technical support to those enterprises that are in transition (transformed into parts and components) and upgrading and transformation. For enterprises that stop production and go bankrupt, financial subsidies, etc., will be granted according to the size of their assets and the total number of employees.

(3)Increase R\&D investment to encourage technological innovation. At present, through the introduction of foreign investment, China's automobile industry has expanded its production scale and raised its efficiency. But at the same time, almost all high-tech technologies such as engines, airbags, and ABS systems rely on foreign technical support, resulting in the "lock-in effect" of the low-end division of labor and the "dependence effect" of imported technologies. Therefore, the government should improve its management level and service level, especially for state-owned enterprises, and further increase investment in research and development. The government should encourage enterprises to innovate and introduce technologies, and promote the transition from a large automobile country to a strong automobile country.

\section{Acknowledgements}

The authors thank the anonymous reviewers for their very constructive and inspirational edits, thanks to the hard work of the journal editors. Thank China National Social Science Fund (14BTJ002)for funding. Of course, the text is at your own risk. 


\section{References}

BAI Xue-jie, \& DAI Xiao-hui. (2006). Analysis of Production Efficiency of China's Major Sedan Enterprises Based on DEA Model [J]. Financial Research, (10), 35-47.

Banker R. D. (1984). Estimating Most Productive Scale Size Using Data Envelopment Analysis [J], European Journal of Operations Research, (17). https://doi.org/10.1016/0377-2217(84)90006-7

Banker R. D., \& Thrall, R. M. (1992). Estimating of Returns to Scale Using Data Envelopment Analysis [J], European Journal of Operations Research, (62).

Büschken, G. (2007). Determinants of Brand Advertising Efficiency Evidence from the German Car Market [J], Journal of Adversing [J]., 36(3), 51-73. https://doi.org/10.2753/JOA0091-3367360304

Garces Peter Davis, \& Eliana. (2013). Quantitative Technology in Competition and Antitrust [M]. Beijing: Renmin University of China Press.

HE Yuan-gui, ZHANG Jie, \& CHEN Jian. (2009). An Empirical Analysis on the Factors Influencing the Economies of Scale of Chinese Automotive Enterprises [J]. Industrial Technology Economics, (4), 66-72.

Hu Hongli. (2005). An Empirical Analysis of Scale Economic Benefits of Chinese Car Enterprises [J]. Science \& Technology Progress and Policy, (04), 77-79.

Jiao Guohua, Jiang Feitao, \& Chen Y. (2007). The Relative Efficiency and Scale Efficiency of Chinese Iron and Steel Enterprises [J]. China Industrial Economy, (10), 37-44.

Maxcy, G., \& Silberston, A. (1959). The motor industry [M], George Allen \& Unwin Ltd.

Zhang Xiaodi, \& Li Xiaozhong. (2011). China's automobile industry market structure and market performance research [J]. China industrial economy, (3), 129-138.

\section{Copyrights}

Copyright for this article is retained by the author(s), with first publication rights granted to the journal.

This is an open-access article distributed under the terms and conditions of the Creative Commons Attribution license (http://creativecommons.org/licenses/by/4.0/). 